\title{
Estudio de hongos contaminantes en el proceso de elaboración de jugos concentrados de naranja y mandarina
}

Sobrero, M.S.*; Basílico, M.L**; Sanchis, J.C.*; Basilico, J.C.**

- Facultad de Bioquimica y Ciencias Biológicas de la Universidad Nacional del Litoral.

* Facultad de Ingeniería Quimica de la Universidad Nacional del Litoral.

Santiago del Estero 2829. ( 3000 ) Santa Fe. E-mail: sobrero @ fbcb.unl.edu.ar

RESUMEN: Hasta la actualidad se consideraba a los jugos concentrados, un medio poco apropiado para el desarrollo de microorganismos, por su baja actividad acuosa, bajo pH, escasez de oxigeno y por haber sido pasteurizados. Todo esto reduce al minimo el ataque bacteriano, por lo que hongos y levaduras son la flora predominante en su alteración. El propósito de este trabajo fue, evaluar la incidencia del proceso de elaboración y las condiciones de higiene en la contaminación por mohos de los jugos concentrados. Se observó como la calidad de la fruta y el ambiente del proceso inciden en el producto final. Se constató la presencia de Neosartorya fischeri que se caracteriza por su termoresistencia. Además, se aislaron mohos xerofilicos, mohos que toleran bajas concentraciones de oxigeno y mohos que metabolizan conservantes. También se identificaron hongos productores potenciales de toxinas de los géneros Alternaria, Aspergillus, Fusarium y Penicillium.

Palabras claves: Jugos - Cítricos - Mohos - Elaboración.

SUMMARY: Analysis of contaminating fungl in the elaboration process of oranges and tangerines concentrated juices. Sobrero, M.S.*; Basillico, M.L**; Sanchis, J.C.*; Basilico, J.C. ${ }^{\star *}$. Concentrated juices have been traditionally considered as little suitable media for the development of microorganisms because of their low pH, water activity, their low dissolved oxygen content and the pasteurization process. All these factors minimize the possibility of development of bacteria and so only some species of yeast and moulds are the microflora commonly found. The aim of this work was to evaluate the incidence of the elaboration process and its hygienic conditions on the characteristic moulds of concentrated juices. It was observed that the fruit quality as well as the ambient in wich the process is carried out determine the fungi found. Neosartorya fischeri, a thermoresistant species, was found in the majority of the samples. Moulds able to develop in low water activity and low oxygen media were also isolated as well as moulds able to metabolise conserving agents. Moulds that are potentially toxicogenic ( Alternaria, Fusarium and Penicillium ) were also found.

Key words: Juices - Citrus - Mould - Elaboration. 